\title{
Improved sanitary landfill design using recirculation of anaerobically treated leachates: generation of advanced design criteria
}

\author{
María Cristina Schiappacasse* \\ Escuela de Ingeniería Bioquímica \\ Pontificia Universidad Católica de Valparaíso \\ Av. Brasil 2147, Valparaíso, Chile \\ E-mail:mschiapp@ucv.cl \\ Juan Palma \\ Escuela de Ingeniería en Construcción \\ Pontificia Universidad Católica de Valparaíso \\ Av. Brasil 2147, Valparaíso, Chile \\ Paola Poirrier \\ Escuela de Ingeniería Bioquímica \\ Pontificia Universidad Católica de Valparaíso \\ Av. Brasil 2147, Valparaíso, Chile \\ Gonzalo Ruiz-Filippi \\ Escuela de Ingeniería Bioquímica \\ Pontificia Universidad Católica de Valparaíso \\ Av. Brasil 2147, Valparaíso, Chile \\ Rolando Chamy \\ Escuela de Ingeniería Bioquímica \\ Pontificia Universidad Católica de Valparaíso \\ Av. Brasil 2147, Valparaíso, Chile \\ Website: http://www.ucv.cl
}

Financial support: FONDECYT project $\mathrm{N}^{\circ}$ 1020795, Chile.

Keywords: hydrological balance, landfill, leachate recycle, municipal solid waste, stabilization.

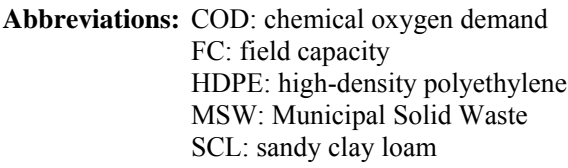

Abbreviations: COD: chemical oxygen demand

FC: field capacity

HDPE: high-density polyethylene

MSW: Municipal Solid Waste

SCL: sandy clay loam

In Latin America, the most accepted disposal systems for Municipal Solid Waste (MSW) are landfills, which nowadays have low rates of stabilization. The objective of this study was to develop design criteria for sanitary landfills which lead to a reduction in the stabilization times of MSW, based on experiment results obtain from a pre-pilot scale operation of two sanitary landfills (0.5 Ton), one with recirculation of leachates treated in an anaerobic digester and the other with recirculation of untreated leachates. This was complemented by another pilot scale sanitary landfill (1440 Ton) with recirculation of leaches treated in an anaerobic filter, and additionally by a computer simulation of leachate generation through the water balance of a theoretical cell of MSW (850 Ton), in which the initial humidity of the MSW and the type of final cover were evaluated. The results obtained on the pre-pilot scale indicate that recirculation of anaerobically treated leachates, when compared to the recirculation of untreated leachates, increased the rate of MSW stabilization, projecting a stabilization time reduction of $72 \%$. In the pilot sanitary landfill an increase in the settling rate of around $200 \%$ was observed when operating with the recirculation of anaerobically treated leachates as opposed to operation without recirculation. The water balance carried out on the theoretical cell of MSW demonstrated the importance to leachate generation of both the initial landfill water saturation and the type of final barrier. From these results it may be stated that it is important for landfill design to maintain waste humidity close to

\footnotetext{
*Corresponding author
} 
its field capacity along with an adequate leachate application rate.

Landfills are one of the most accepted disposal systems for Municipal Solid Waste (MSW). However, these systems have a low rate of organic matter degradation, which means low biogas productivity and a shorter useful life of the landfill, due to the very slow nature of the waste settling process.

It has been demonstrated that the addition of water has a positive effect on the stabilization of MSW in landfills, nevertheless, as landfills have an impermeable membrane system and a sealed cover, the addition of humidity is blocked although it is essential for the organic matter degradation processes (Reinhart and Al-Yousfi, 1996).

For example, in the case of tropical landfills where high temperatures and high water loss due to evaporation are registered, it has been demonstrated in experiments using reactors that the addition of water along with leachate recirculation may control the humidity in the interior of the landfill, thus improving its performance in terms of cumulative methane production and decreasing the required stabilization time (Sanphoti et al. 2006). With regard to stabilization time, there exists sufficient documentation to establish the benefits of leachate recirculation within sanitary landfills, since it increases the degradation of organic matter (Benson et al. 2007, Francois et al. 2007), it accelerates the cultivation and propagation of biological activities in a landfill to enhance its treatment (Wang et al. 2006), it increases biogas production (Francois et al. 2007), settlings are produced faster and in greater quantity (Benson et al. 2007; Olivier and Gourc, 2007), it can improve the leachate quality by decreasing chemical oxygen demand (COD), suspended solid and $\mathrm{NH}_{4}{ }^{+}$ concentrations (Zhao et al. 2006), it is possible to shorten the time in which leachate quality becomes stabilized (Wang et al. 2006), and it reduces the landfill stabilization time from several decades to 2 or 3 years, hence minimizing the time during which an adverse impact on the environment could be produced (Reinhart, 1996).

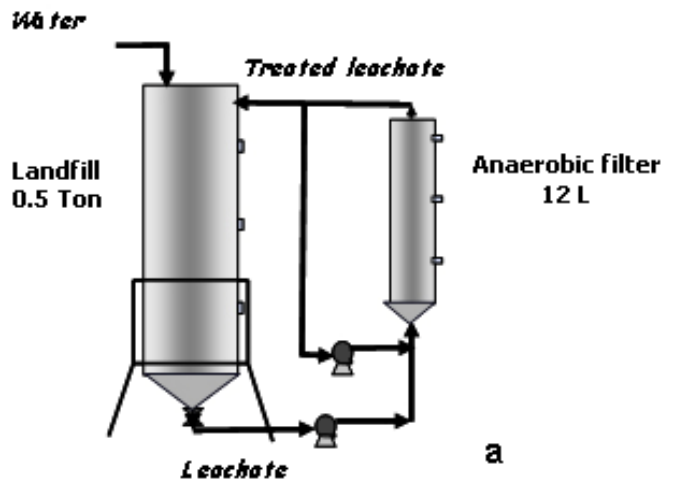

Additionally, recirculation of leachates which have been previously treated in an anaerobic digester can solve the problems of inhibition in the landfill in different ways: (1) acids formed in the landfill will be removed and treated; (2) leachates that enter the landfill will have sufficient alkalinity; and (3) leachates will provide inoculums for the landfill in order to quickly establish a microbial population with an adequate balance between acidogenic and methanogenic organisms (O'Keefe and Chynoweth, 2000).

Therefore, it may be stated that anaerobic digestion of leachates and their subsequent recirculation to the landfill involves the decomposition of organic matter in two phases. The first phase takes place in the landfill cells and it comprises the hydrolytic and acidogenic stages. The second phase, which is carried out in the anaerobic digester, is where the acetogenic and methanogenic stages occur (Mata-Alvarez, 1987; O'Keefe and Chynoweth, 2000).

From a kinetic and also an operational point of view, separation into two phases increases the possibility of maintaining an optimal environment for each microbial group, substantially increasing the associated reactions. In the case of MSW, the hydrolytic stage is the limiting phase in relation to the global rate of the process, this is due to the limited contact time of the solid surface with the extracellular enzymes in the landfill (Mata-Alvarez, 1987).

This study is focused on the generation of advanced design criteria for sanitary landfills, with the aim of achieving shorter stabilization periods for MSW through experimental data obtained from landfills on a pre-pilot and pilot scale, and on a subsequent hydrological modeling of a theoretical MSW cell based on the obtained results.

\section{MATERIALS AND METHODS}

\section{Pre-pilot scale}

The performance of a 0.5 Ton MSW pre-pilot landfill was evaluated for 650 days at $30^{\circ} \mathrm{C}$. Two design approaches were considered: in the first, leachates were treated at $37^{\circ} \mathrm{C}$

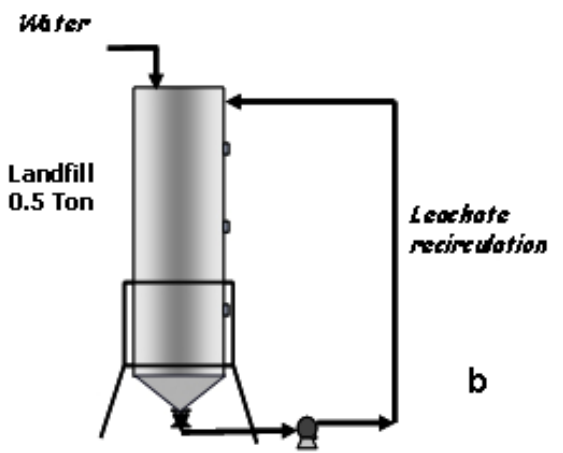

Figure 1. Pre-pilot landfill with and without anaerobic treatment of leachate recirculation 


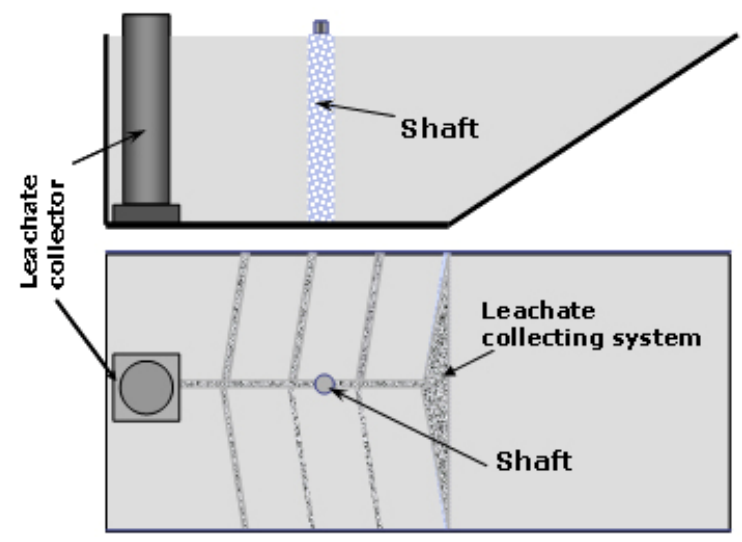

Figure 2. Frontal and top views of the pilot scale landfill.

in a $12 \mathrm{~L}$ anaerobic filter reactor before their recirculation to the landfill. In the second case, leachates were recirculated without treatment. The pre-pilot landfills were $0.8 \mathrm{~m}$ in diameter, $2.4 \mathrm{~m}$ in height, and are shown schematically in Figure 1a and Figure 1b. Landfills were filled with synthetic MSW, formulated according to the typical composition of the MSW of the city of Valparaiso (Chile), and compacted to a final density of $0.5 \mathrm{Ton} / \mathrm{m}^{3}$, using a $20 \mathrm{~cm}$ final cover composed of a clay barrier layer. The influent water (which simulated the rain fall of the city of Valparaiso) and recirculated leachates, with or without anaerobic treatment, were distributed homogenously below the cover.

The anaerobic filter was $0.9 \mathrm{~m}$ in height and $0.13 \mathrm{~m}$ in diameter and it was filled with plastic corrugated rings with a surface area of $573 \mathrm{~m}^{2} / \mathrm{m}^{3}$, randomly distributed inside the reactor.

Pre-pilot landfills with recirculation of treated and untreated leachates were initially saturated with water, 110 $\mathrm{L}$ and $95 \mathrm{~L}$, respectively, for a period of approximately two weeks.

\section{Pilot scale}

Pilot scale experiments were carried out in a 1440 Ton
MSW sanitary landfill located in the city of Valparaiso, with a $30 \mathrm{~cm}$ final clay barrier for a period of 640 days. In this case the leachates were treated at $37^{\circ} \mathrm{C}$ in a $6.1 \mathrm{~m}^{3}$ anaerobic filter.

The landfill was $14.9 \mathrm{~m}$ in length, $10 \mathrm{~m}$ in width and $6 \mathrm{~m}$ in depth. It had a ramp of $20.2 \times 10 \mathrm{~m}^{2}$, as represented in Figure 2. In addition, an impermeabilization system with 1 mm thick high-density polyethylene (HDPE) geomembrane was used.

The landfill also included a system for leachate drainage, a special system for biogas collecting and a chamber for leachate collection from which leachates were pumped to the anaerobic filter. It also had a system for treated leachate distribution below the final cover.

The anaerobic filter was $2.3 \mathrm{~m}$ in diameter and $1.5 \mathrm{~m}$ in height. The support medium used as microbial biofilm was Flocor-R type rings, with a specific surface area of 612 $\mathrm{m}^{2} / \mathrm{m}^{3}$.

In order to reduce the start up period, the MSW landfill was initially saturated with approximately $120 \mathrm{~m}^{3}$ of water. This process was done gradually to ensure the homogenous saturation of the system. During the operation of the landfill, $24 \mathrm{~m}^{3}$ of water were added between days 263 and 377 to generate leachates, simulating rain fall. The settlings were measured with a topography level device, in accordance with the points indicated in Figure 3.

\section{Theoretical cell}

A simulation of the hidrological balance of an 850 Ton MSW theoretical cell was carried out for a five year period, using weather data for the environmental characteristics of the city of Valparaiso. Variations in leachate production were computed. Two initial humidity conditions were considered: i) $0.17 \mathrm{v} / \mathrm{v}$ which corresponds to a typical MSW humidity level, and ii) $0.25 \mathrm{v} / \mathrm{v}$ humidity, corresponding to field capacity (FC). Additionally, two types of final soil cover were considered: a) a $50 \mathrm{~cm}$ thick sandy clay loam (SCL) layer (soil which allows vertical percolation) plus a geotextile liner, a $10 \mathrm{~cm}$ lateral draining layer (gravel), a $1.5 \mathrm{~mm}$ HDPE liner and a $20 \mathrm{~cm}$ barrier

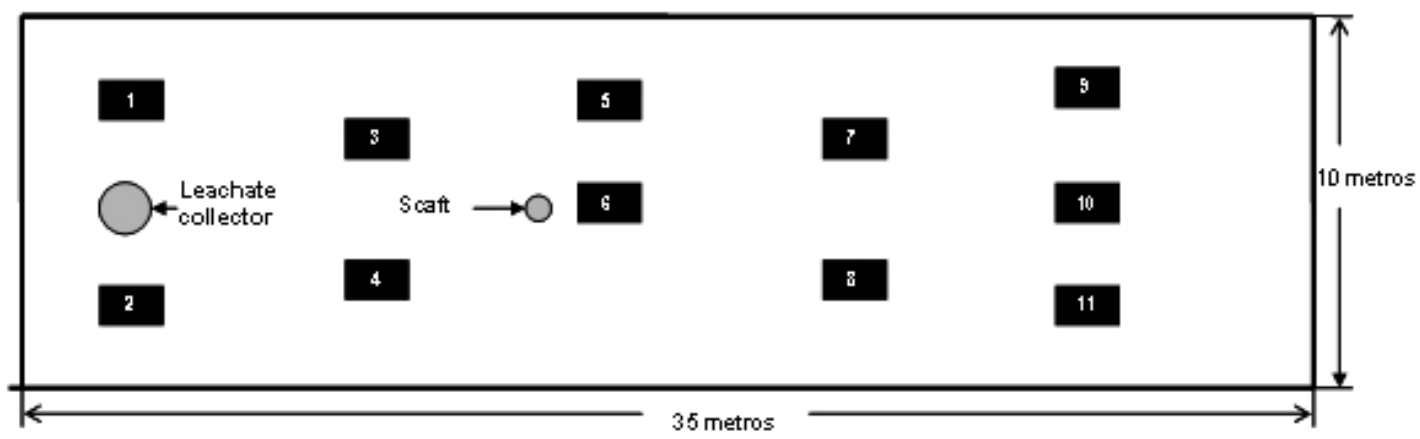

Figure 3. Location of settling measurement points in pilot MSW landfill. 


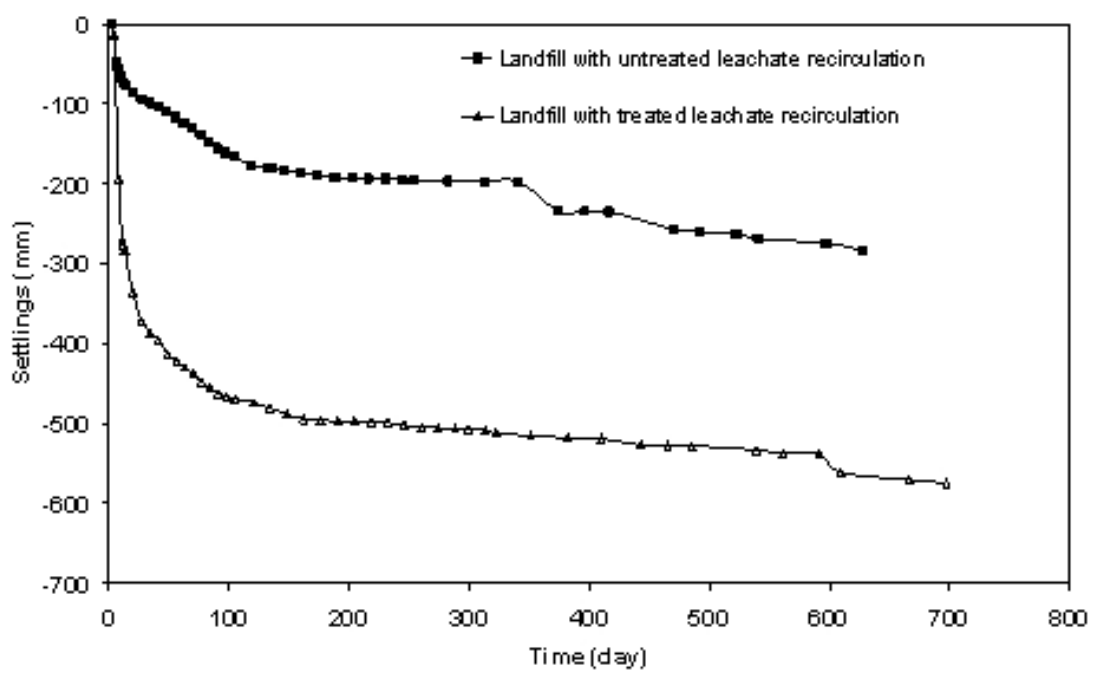

Figure 4. Settling evolution in the 0.5 Ton pre-pilot scale landfill.

soil liner (compacted clay), named multilayer; and b) a 50 $\mathrm{cm}$ thick SCL, named SCL monolayer. Evaluation conditions are summarized in Table 1.

Rain water percolation was calculated using HELP-V3.07 (modeling software for the hydrological evaluation of landfill performance). Leachate production was estimated based on the reduction of the FC of the MSW over time, due to the increase in its density.

The ratio of FC to MSW density was determined experimentally, for which 9 PVC columns, $2 \mathrm{~m}$ in diameter and $1 \mathrm{~m}$ in length, were installed, and which had a drainage cap at the bottom over which was placed $0.73 \mathrm{~m}$ of compacted MSW at a density of $0.4 \mathrm{Ton} / \mathrm{m}^{3}$ ( 3 columns), $0.6 \mathrm{Ton} / \mathrm{m}^{3}$ ( 3 columns) and $0.8 \mathrm{Ton} / \mathrm{m}^{3}$ (3 columns), with a water diffuser in the upper zone. Water was added to the columns until a leachate was generated and the FC was determined from the residue as the coefficient between the volume of water content (retained water plus initial water) and the total volume of the residue.
The variation in the density of the MSW over time was estimated considering an initial value of $0.5 \mathrm{Ton} / \mathrm{m} 3$ and its increase caused by the reduction in the volume of the theoretical cell, which is in turn due to settling.

\section{Analysis}

Chemical analysis of $\mathrm{COD}$ and $\mathrm{pH}$ was carried out according to the Standard Methods for the Examination of Water and Wastewater Treatment (American Public Health Association, 1992).

\section{RESULTS AND DISCUSSION}

\section{Pre-pilot}

Figure 4 presents the settlings produced with the pre-pilot MSW landfills. The highest settlings were produced in the first 105 days of operation, reaching, in this period, a settling of $23.5 \%$ and $6.5 \%$ respectively for the landfill with treated leachate recirculation and for the landfill with recirculation of untreated leachates. At the end of the

Table 1. Evaluation conditions used for the hydrological balance computations.

\begin{tabular}{|c|c|c|}
\hline Evaluation conditions & Humidity (v/v) & $\begin{array}{c}\text { Type of } \\
\text { soil cover }\end{array}$ \\
\hline E-1 & 0.17 & Multilayer \\
\hline E-2 & 0.17 & SCL monolayer \\
\hline E-3 & 0.25 & Multilayer \\
\hline E-4 & 0.25 & SCL monolayer \\
\hline
\end{tabular}




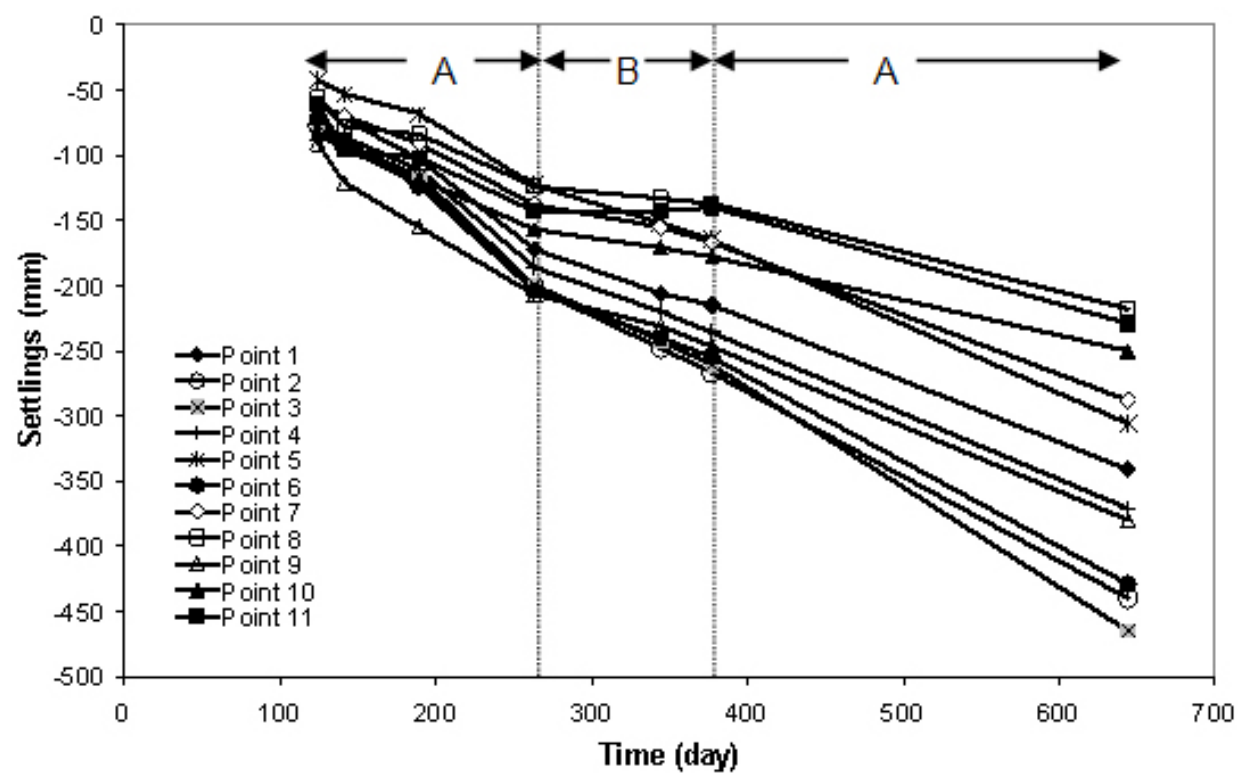

Figure 5. Settling measured at different points of the pilot sanitary landfill under different regimes of recirculation of treated leachates. A: period with recirculation of treated leachates and B: period without recirculation of treated leachates.

operation period the landfill with treated leachate recirculation reached $29 \%$ settling (690 days), while the landfill with untreated leachate recirculation obtain a value of only $14 \%$ (630 days).

The settling data for each of the landfills was adjusted to the hyperbolic model proposed by Ling et al. (1998), as shown in Equation 1.

$\mathrm{S}^{*}=\mathrm{t}^{*} /\left[1 / \mathrm{r}_{0}+\mathrm{t} / \mathrm{S}_{\mathrm{ult}}\right] \quad$ [Equation 1]

Where, $t^{*}$ : difference between time to be predicted $(t)$ and the initial time of measuring $\left(\mathrm{t}_{0}\right),\left(\mathrm{t}^{*}=\mathrm{t}-\mathrm{t}_{0}\right)$, days; $\mathrm{S}^{*}$ : difference between the measured settling at $t$ and the measured settling at $t_{0},\left(S^{*}=S-S_{0}\right), m m ; r_{0}$ : initial rate of settling at $\mathrm{t}_{0}, \mathrm{~mm} /$ days; $\mathrm{S}_{\mathrm{ult}}$ : Final settling $(\mathrm{t} \rightarrow \infty), \mathrm{mm}$

Equation 2 and Equation 3 correspond to the modeling expressions for the landfills with recirculation of treated leachates and with recirculation of untreated leachates, respectively.

$$
\begin{aligned}
& \mathrm{S}=(585.0 \mathrm{t}-1755.0) /(34.4+\mathrm{t}) \quad \text { [Equation 2] } \\
& \mathrm{S}=(455.0 \mathrm{t}-1365.0) /(413.6+\mathrm{t}) \quad \text { [Equation 3] }
\end{aligned}
$$

Stabilization times of the pre-pilot MSW landfills were calculated using Equation 2 and Equation 3. Stabilization was considered to be reached when daily variation in settling rates was close to $0.0016 \%$. Settling percentages of $29 \%$ over 3.7 years and $21 \%$ over $13.3 \%$ were obtained for landfills with recirculation of treated leachates and for landfills with recirculation of untreated leachates, respectively.
Therefore, the simulation indicates that the settling percentage increase $38 \%$ and reduces stabilization time by around $72 \%$ when the sanitary landfill is operated with recirculation of treated leachates, compared to the recirculation of leachates without treatment.

Benson et al. (2007) determined settlings of $22-25 \%$ in a period of 1000 days in a bioreactor with recirculation of untreated leachates, values which are slightly higher than the values projected for the same period for the landfill with recirculation of untreated leachates $(16 \%)$, but less than those for the landfill operated with recirculation of treated leachates $(28 \%)$.

The aforementioned results indicate the significant influence of the recirculation of anaerobically treated leachates on initial settling rate and on the final degree of settling which may be achieved.

Leachates produced in the landfill had a mean COD of $51600 \mathrm{mg} / \mathrm{L}$ and $12900 \mathrm{mg} / \mathrm{L}$ and a pH of 5.5 and 7.7 in the treated and untreated leachate currents, respectively.

The recirculation of anaerobically treated leachates decreases the stabilization time of the MSW through the different mechanisms proposed by different researchers (O'Keefe and Chynoweth, 2000; Benson et al. 2007) and additionally, a higher level of biodegradation of the organic matrix of the MSW may be occurring, which would be the cause of the increased initial settling rate of the landfills and of the generation of leachate which is richer in organic matter. Furthermore, the alternative of treating recirculated leachates behaves as a two-phase reactor where the hydrolytic and acidogenic phases occur in the landfill, 
while the methanogenesis takes place in the anaerobic filter. The decrease in $\mathrm{pH}$ of the generated leachate may be attributed to the generation of volatile fatty acids from the solubilized organic matter, since these compounds are produced in hydrolytic-acidogenic reactors (De La Rubia et al. 2009). However, it can be observed that for the efficient operation of the two-phase anaerobic digestion of the organic solid residue, the concentration of volatile fatty acids and the $\mathrm{pH}$ must be controlled, since at low $\mathrm{pH}$ levels non-dissociated acids become inhibitors (Babel et al. 2004).

\section{Pilot}

As shown in Figure 5, the pilot landfill was operated with recirculation of anaerobically treated leachates, denominated period $\mathrm{A}$, with the exception of an intermediate period, denominated period $\mathrm{B}$, corresponding to days 263 to 377 , in which no leachate was generated. The results obtained showed that with the recirculation of treated leachates the mean settling speed doubled in comparison to the non-recirculation period (Figure 5).

Settling data measured in the pilot scale landfill was fitted to the hyperbolic model reported by Ling et al. (1998) (Equation 1), thus obtaining Equation 4, which was then used to simulate the hydrolytic balance in the theoretical cell:

$S=(939.5 t-14091.9) /(1032.4+t)$

[Equation 4]

The stabilization time of the pilot landfill was estimated at 21 years, and was calculated using Equation 4 with the same consideration used for the pre-pilot scale with regard to daily variation percentage in settling rate. The stabilization time on the pilot scale is higher than the values obtained on the pre-pilot scale, which is attributed to the drought (lack of rainfall) which occurred during its operation, as there were long periods without leachate generation and their subsequent recirculation.

\section{Theoretical cell}

The ratio between FC and the MSW density obtained in the operation of the columns is shown in the following equation:

$\mathrm{FC}=0.05+1.45 \cdot \mathrm{e}^{-3.96 \cdot \rho} \quad$ [Equation 5]

Where, FC: field capacity, $\mathrm{v} / \mathrm{v} ; \rho$ : density, Ton $/ \mathrm{m}^{3}$.

The hidrological balance of the theoretical cell showed that if there is no initial liquid saturation of the landfill, there is no generation of leachates in experiment E-1 (nomenclature according Table 1), and in experiment E-2, leachates are generated only after 16 months. This shows that it is fundamental to increase the level of humidity in the landfill until FC is reached by means of the addition of water or through the management of leachates, such as that proposed by Suna Erses and Onay (2003) which involves saturating the landfill with leachates from old cells.

For the other studied conditions, Figure 6 and Figure 7 show the variation over time of the monthly production of leachates, experiments E-3 and E-4, respectively, for a range of 100 to $60 \%$ recirculation rates. It can be seen that the soil cover has a significant influence over leachate generation, since the monolayer final cover presented a maximum leachate production almost three times higher

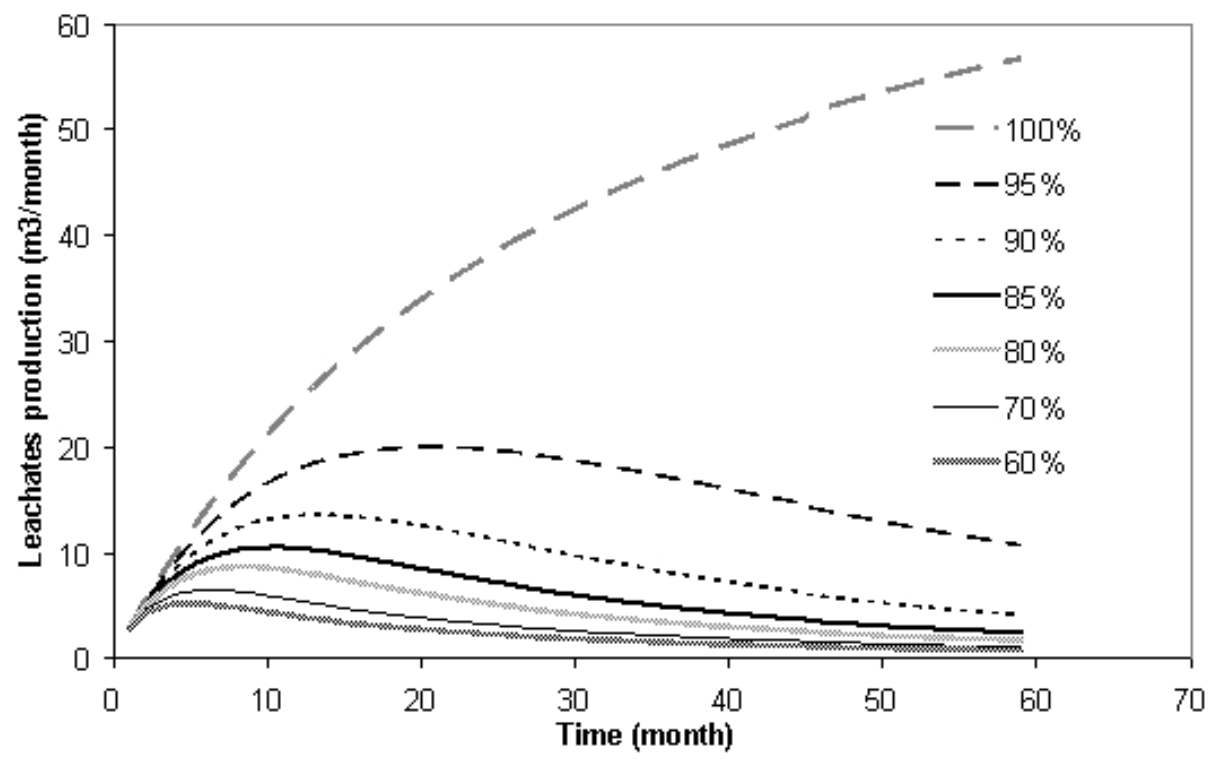

Figure 6. Variation of leachate production for experiment E-3 (0.25 v/v (FC) and multilayer final cover) for different leachate recirculation percentages. 


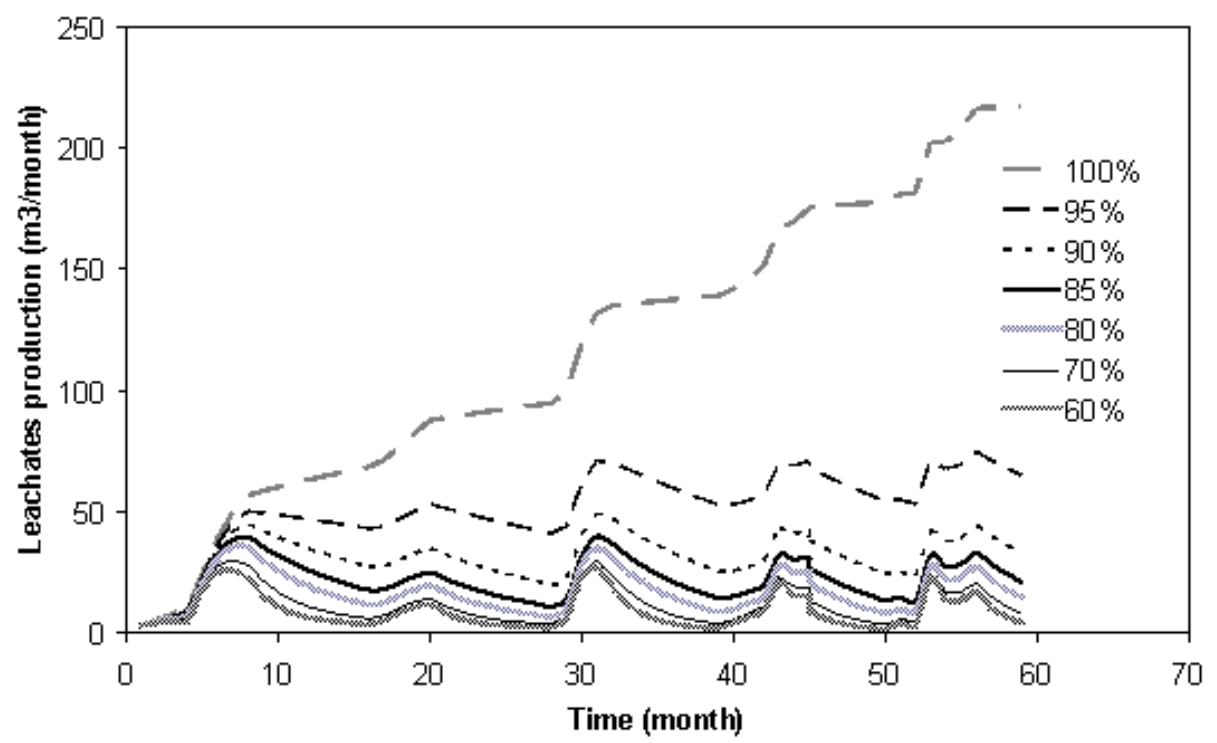

Figure 7. Variation of leachate production for experiment E-4 (0.25 v/v (FC) and monolayer final cover) for different leachate recirculation percentages.

than the multilayer final cover.

It may be observed in the simulation that during the first year the highest reductions of the FC of the MSW are generated, with this period representing $43 \%$ of the total loss over the 5 years. In the case of experiments E- 3 and E4 , in which initial humidity is at $\mathrm{FC}$, and the difference is in the type of final cover used on the cell, it is observed over the 5 years of simulation that practically all leachates originate from the loss of FC of the MSW in experiment E3 . On the other hand, in experiment E- 4 , only $26 \%$ of the leachates originate from loss of the FC of the MSW, with the rest resulting from the contribution of the percolation of rainwater. This indicates that if a new MSW cell is initially saturated with water or leachates from other cells, it would not be necessary to recirculate leachates to maintain the humidity of the MSW at the level of its FC. However, it has been observed in this study that the recirculation of anaerobically treated leachates is necessary since it increases the initial settling rate and the final degree of settling of the landfill, and moreover, as indicated by Benson et al. (2007) a raise in the leachate application rate increases the degree of settling.

In Figure 6 and Figure 7 it may be observed that if $100 \%$ of the generated leachates are recirculated in the landfills, leachate production maintains an increase over time, and this is not the case if the recirculation level is $95 \%$ or less. The maximum rates of leachate application calculated corresponding to $100 \%$ recirculation for experiments E-3 and E-4, at the end of the simulation period the values reached are $11 \mathrm{~L} / \mathrm{m}^{2}$ day and $43 \mathrm{~L} / \mathrm{m}^{2}$ day, respectively. These values are very high in comparison with those used in other research (Zhao et al. 2006; Francois et al. 2007) who, on a laboratory scale, have applied rates up to $8 \mathrm{~L} / \mathrm{m} 2$ day and, on a large scale, up to $0.45 \mathrm{~L} / \mathrm{m}^{2} \mathrm{x}$ day (Morris et al. 2003; Benson et al. 2007). Hence, the leachate recirculation percentage must be adjusted in each situation to acceptable values.

\section{CONCLUDING REMARKS}

From this study, it can be concluded that it is possible to increase the settling of MSW landfills using a process design which includes an initial water saturation of the MSW, a system for leachate collection, leachate treatment through an anaerobic reactor, and their total or partial recirculation back into the landfill. Furthermore, during the operation of the landfill, it is important to maintain MSW humidity close to its $\mathrm{FC}$, as well as an adequate treated leachate application rate.

Finally, it is important to consider the appropriate selection of final cover, taking into account the location of the landfill in order to control leachate volume and to achieve the best operating conditions for humidity maintenance. With regard to this factor it can be pointed out that a multilayer cover produces lower leachate flow.

\section{REFERENCES}

American Public Health Association (APHA). Standard Methods for the Examination of Waters and Wastewaters, $18^{\text {th }}$ ed., APHA, WCPF, AWWA, Washington DC, USA, 1992. ISBN 0-87553-207-1.

BABEL, Sandhya; FUKUSHI, Kensuke and SITANRASSAMEE, Bunpot. Effect of acid speciation on 
solid waste liquefaction in an anaerobic acid digester. Water Research, May 2004, vol. 38, no. 9, p. 2417-2423.

BENSON, C.H.; BARLAZ, M.A.; LANE, D.T. and RAWE, J.M. Practice review of five bioreactor/recirculation landfills. Waste Management, 2007, vol. 27, no. 1, p. 13-29.

DE LA RUBIA, M.A.; RAPOSO, F.; RINCÓN, B. and BORJA, R. Evaluation of the hydrolytic-acidogenic step of a two-stage mesophilic anaerobic digestion process of sunflower oil cake. Bioresource Technology, September 2009, vol. 100, no. 18, p. 4133-4138.

FRANCOIS, V.; FEUILLADE， G.; MATEJKA， G.; LAGIER, T. and SKHIRI, N. Leachate recirculation effects on waste degradation: Study on columns. Waste Management, 2007, vol. 27, no. 9, p. 1259-1272.

LING, Hoe I.; LESHCHINSKY, Dov; MOHRI, Yoshiyuki and KAWABATA, Toshinori. Estimation of municipal solid waste landfill settlement. Journal of Geotechnical and Geoenvironmental Engineering, January 1998, vol. 124, no. 1, p. 21-28.

MATA-ALVAREZ, Joan. A dynamic simulation of a two phase anaerobic digestion system for solid wastes. Biotechnology and Bioengineering, November 1987, vol. 30 , no. 7 , p. 844-845.

MORRIS, J.W.F.; VASUKI, N.C.; BAKER, J.A. and PENDLETON, C.H. Finding from long-term monitoring studies al MSW landfill facilities with leachate recirculation. Waste Management, 2003, vol. 23, no. 7, p. 653-666.

O'KEEFE, D.M. and CHYNOWETH, D.P. Influence of phase separation, leachate recycle and aeration on treatment of municipal solid waste in simulated landfill cells. Bioresource Technology, March 2000, vol. 72, no. 1, p. 5566.

OLIVIER, Frank and GOURC, Jean-Pierre. Hydromechanical behavior of municipal solid waste subject to leachate recirculation in a large-scale compression reactor cell. Waste Management, 2007, vol. 27, no. 1, p. 44-58.

REINHART, Debra R. Full-scale experiences with leachate recirculation landfills: case studies. Waste Management \& Research, 1996, vol. 14, no. 4, p. 347-365.

REINHART, Debra R. and AL-YOUSFI, A. Basel. The impact of leachate recirculation on municipal solid waste landfill operating characteristics. Waste Management \& Research, 1996, vol. 14, no. 4, p. 337-346.

SANPHOTI, N.; TOWPRAYOON, S.; CHAIPRASERT, P. and NOPHARATANA, A. Enhancing waste decomposition and methane production in simulated landfill using combined anaerobic reactors. Water Science and Technology, 2006, vol. 53, no. 8, p. 243-251.

SUNA ERSES, A. and ONAY, T.T. Accelerated landfill waste decomposition by external leachate recirculation from an old landfill cell. Water Science and Technology, 2003, vol. 47, no. 12, p. 215-222.

WANG, Qi; MATSUFUJI, Yasushi; DONG, Lu; HUANG, Qifei; HIRANO, Fumiaki and TANAKA, Ayako. Research on leachate recirculation from different types of landfills. Waste Management, 2006, vol. 26, no. 8, p. 815-824.

ZHAO, Qing-liang; LIU, Xue-yan; QI, Xu-dong and LIU, Zhi-gang. Landfill leachate production, quality and recirculation treatment in northeast China. Journal of Environmental Sciences, 2006, vol. 18, no. 4, p. 625-628. 